\title{
Pengembangan Sensor Air Hujan Menggunakan Hukum Archimedes Untuk Jemuran Pakaian Otomatis Berbasis Lingkungan Sebagai Media Pembelajaran Fisika
}

\author{
Yoky Novra Silta \\ Program Studi Pendidikan Fisika Universitas Ahmad Dahlan \\ J1. Prof. Dr. Soepomo, SH. Janturan Yogyakarta \\ Surat-e: ssatryareserved@yahoo.com
}

Materi fluida statis pada pokok bahasan hukum Archimedes merupakan materi yang abstrak dimana hukum Archimedes dan contoh lain aplikasinya hanya dibayangkan oleh siswa. Pemahaman materi fluida statis pada pokok bahasan hukum Archimedes perlu diadakan upaya pengkongkritan. Maka dari itu, peneliti mengembangkan alat peraga fisika inovatif berbasis lingkungan berupa sensor air hujan sederhana untuk jemuran otomatis. Peran peraga salah satunya adalah menjadikan konsep yang abstrak menjadi lebih konkrit. Tujuan dari penelitian ini adalah mengembangkan alat peraga fisika inovatif berbasis lingkungan yang dapat digunakan sebagai media pembelajaran fisika yang menarik dan bermakna, serta mengetahui kelayakan media pembelajaran tersebut dalam pembelajaran fisika pada materi fluida statis untuk siswa SMA kelas X.

Subjek penelitian ini adalah siswa di kelas X SMA Negeri 5 Yogyakarta. Desain penelitian ini menggunakan desain ADDIE (Analysis, Design, Development, Implementation, Evaluation). Instrumen yang digunakan dalam penelitian ini berupa angket respon untuk ahli materi dan ahli media (dosen dan guru fisika), angket respon untuk siswa dan nilai hasil belajar dari pretest dan posttest. Data yang diperoleh selanjutnya dianalisis secara kuantitatif dan kualitatif.

Berdasarkan analisis penilaian oleh ahli materi dan ahli media, alat peraga fisika inovatif sensor air hujan sebagai media pembelajaran untuk siswa SMA kelas X, jika di rata-rata diperoleh hasil 9I\% yang berada pada kategori sangat layak. Kemudian untuk angket respon siswa terhadap penggunaan alat peraga fisika inovatif diperoleh rata-rata sebesar $85,77 \%$ yang berada pada kategori sangat layak. Untuk hasil pretest sebelum menggunakan alat peraga diperoleh nilai rata-rata 54,5. Sedangkan dari analisis terhadap hasil posttest setelah menggunakan alat peraga diperoleh rata-rata 84,33 . Berdasarkan hasil analisis tersebut dapat disimpulkan bahwa alat peraga yang dirancang, dibuat dan dikembangkan layak digunakan sebagai alat peraga dalam pembelajaran.

Kata kunci: sensor, air hujan, alat peraga, lingkungan, fluida statis.

\section{Pendahuluan}

Kemajuan ilmu pengetahuan dan teknologi telah berpengaruh terhadap penggunaan alat-alat bantu mengajar di sekolah-sekolah dan lembaga-lembaga pendidikan lainnya. Bagi sekolah-sekolah yang sudah maju dan mampu, telah menggunakan alat-alat tersebut sebagai alat bantu mengajar sehingga pembelajaran menjadi lebih efektif, efisien dan menyenangkan[I].

Penggunaan alat-alat bantu mengajar, alat-alat bantu peraga pendidikan, audio, visual, dan audio-visual serta perlengkapan sekolah serta perlengkapan peralatan kerja lainnya, disesuaikan dengan perkembangan tersebut. Semua peralatan dan perlengkapan sekolah tersebut harus disesuaikan dengan tuntutan kurikulum dan materi, metode, dan tingkat kemampuan pembelajar (siswa) untuk mencapai tujuan pembelajaran[2].

Pengajar diharapkan dapat menggunakan alat-alat atau perlengkapan tersebut secara efektif dan efisien dalam pembelajaran di kelas. Pengajar juga diisyaratkan untuk dapat menggunakan berbagai alat yang murah, efisien, mampu dimiliki sekolah, baik yang dibuat sendiri oleh pengajar, maupun alat-alat kompensional yang sudah 
Pengembangan Sensor Air Hujan Menggunakan Hukum Archimedes Untuk Jemuran Pakaian Otomatis Berbasis Lingkungan Sebagai Media Pembelajaran Fisika

tersedia dan dimiliki sekolah. Pengajar sebagai tenaga professional dituntut untuk selalu mengem bangkan diri sejalan dengan kemampuan ilmu pengetahuan dan teknologi[I].

Dalam pembelajaran fisika ketepatan memilih media pembelajaran merupakan faktor utama dalam mengoptimalkan hasil pembelajaran. Untuk memilih media yang tepat seorang guru perlu mempertimbangkan berbagai landasan agar media yang dipilih benar-benar sesuai dengan tingkat pemahaman kemampuan berfikir, psikologis, dan kondisi sosial siswa. Sebab penggunaan media yang tidak sesuai dengan kondisi anak akan menyebabkan tidak berfungsinya media secara optimal.

Guru harus bisa menciptakan suasana dalam kelas agar terjadi interaksi belajar mengajar yang dapat memotivasi untuk belajar dengan baik dan sungguh-sungguh. Oleh sebab itu siswa perlu diberikan sebuah stimulus yang baik dalam pembelajaran yang menggunakan media agar tercipta kondisi pembelajaran yang bisa menarik siswa untuk belajar menjadi lebih baik. Namun untuk menciptakan suasana pembelajaran seperti itu bukan persoalan yang mudah. Diperlukan komponen-komponen lain untuk mendukung proses pembelajaran agar mudah dan menyenangkan. Salah satu komponen yang bisa memudahkan siswa belajar dengan menggunakan alat peraga, terlebih mengutamakan lingkungan.

Peran peraga salah satunya adalah menjadikan konsep yang abstrak menjadi lebih konkrit. Pada pembelajaran fisika materi fluida statis pokok bahasan hukum Archimedes baru sebatas pemaparan contoh dan aplikasinya yang sederhana tanpa menggunakan teknologi sehingga dengan adanya alat peraga fisika inovatif berteknologi ini dapat meningkatkan motivasi dan pemahaman siswa dalam belajar fisika sehingga menjadikan konsep abstrak menjadi lebih konkrit berteknologi khususnya dalam materi fluida statis akan lebih baik.

Berdasarkan hasil observasi yang lakukan di SMA Negeri 5 Yogyakarta, masalah-masalah yang ditemukan di sekolah yaitu tidak adanya alat peraga inovatif untuk materi fluida statis. Siswa menganggap bahwa pelajaran fisika sulit terutama pada materi fluida statis. Dalam proses pembelajaran, media yang di gunakan untuk menyampaikan materi kepada siswa dianggap kurang memotivasi siswa dalam belajar. Hal ini menyebabkan nilai prestasi belajar siswa menjadi rendah.

Keterbatasan alat peraga pembelajaran di sekolah dikarenakan mahalnya harga alat peraga dan minimnya dana untuk membeli alat-alat peraga tersebut. Dalam pembelajaran fisika khususnya untuk materi listrik statis keterbatasan alat peraga ini dapat diatasi dengan pengembangan peraga pembelajaran berbasis lingkungan.

Alat peraga berbasis lingkungan merupakan alat peraga yang terbuat dari bahan-bahan bekas atau barang-barang yang mudah kita temukan di sekitar lingkungan kita[3].
Dalam penelitian ini, peneliti mengembangkan alat peraga fisika berteknologi meng gunakan basis lingkungan sehingga biaya untuk pembuatan alat peraga fisika relatif murah dengan tujuan memproteksi lingkungan dan memanfaatkan sisa produk limbah.

Pelaksanaan pembelajaran fisika yang aktif dan kreatif dapat diwujudkan dalam perancangan alat peraga fisika inovatif sehingga siswa termotivasi dalam belajar fisika. Oleh karena itu peneliti merasa perlu untuk melakukan penelitian dengan tema "Pengembangan Sensor Air Hujan Menggunakan Hukum Archimedes untuk Jemuran Pakaian Otomatis Berbasis Lingkungan Sebagai Media Pembelajaran Fisika" dengan harapan peneliti bahwa alat peraga sains fisika inovatif ini mampu menjembatani guru dalam menjelaskan gejala-gejala fisika disekitar kita.

Berdasarkan latar belakang yang telah dikemukakan diatas, dapat diidentifikasi masalah sebagai berikut :

I. Guru belum mampu menyelenggarakan pembelajaran yang menarik dan menyenangkan.

2. Proses pembelajaran masih monoton, dan menggunakan media seadanya dalam pembelajaran mengakibatkan siswa merasa bosan mengikuti pembelajaran.

3. Tidak adanya alat peraga inovatif di SMAN 5 Yogyakarta terutama pada materi fluida statis.

4. Pelajaran Fisika dianggap sebagai mata pelajaran yang sulit bagi siswa.

5. Kurangnya motivasi belajar siswa, salah satunya pada materi fluida statis.

Penelitian ini bertujuan untuk:

I. Untuk mengembangkan alat peraga fisika inovatif untuk pembelajaran Fluida Statis.

2. Untuk mengetahui kelayakan alat peraga dengan pembelajaran fisika pada materi Fluida Statis di SMA Negeri 5 Yogyakarta

\section{Metode Penelitian/Eksperimen}

Menurut Sugiyono[4] metode penelitian dan pengembangan atau dalam bahasa inggrisnya Research and Development adalah metode penelitian yang digunakan untuk menghasilkan produk tertentu, dan menguji keefektifan produk tersebut. Penelitian ini bertujuan untuk menciptakan produk baru yang berupa alat peraga untuk siswa SMP kelas IX. Penelitian ini diklasifikasikan dalam Penelitian dan Pengembangan atau Research and Development ( $\mathrm{R} \& \mathrm{D})$.

Dalam penelitian ini, prosedur yang digunakan mengacu pada desain pengembangan model ADDIE (Analysis, Design, Development, Implementation, Evaluation). Pemilihan model pengembangan ini didasarkan pada alasan bahwa tahapan-tahapan dasar 
Pengembangan Sensor Air Hujan Menggunakan Hukum Archimedes Untuk Jemuran Pakaian Otomatis Berbasis Lingkungan Sebagai Media Pembelajaran Fisika

desain pengembangan ADDIE sederhana, mudah dipelajari, simpel serta lebih mudah dipraktikan dalam pengembangan media pembelajaran.

Kelima fase atau tahap dalam model ADDIE dilakukan secara sistematis. Model desain sistem pembelajaran ADDIE dengan komponen-komponennya dapat dijelaskan sebagai berikut ini.

I. Analysis (tahap analisis)

Salah satu masalah dalam dunia pendidikan yang masih terjadi saat ini yaitu terbatasnya media pembelajaran yang dapat membangun pengetahuan peserta didik. Berdasarkan pengamatan di SMA Negeri 5 Yogyakarta, dalam pembelajaran peserta didik belum menggunakan alat peraga fisika inovatif untuk materi fluida statis pada pokok bahasan hukum Archimedes. Peserta didik hanya menggunakan buku paket pelajaran yang diberikan oleh guru.

2. Design (tahap perencanaan)

Pada tahap ini, kegiatan yang dilakukan oleh peneliti adalah merancang suatu media ajar berupa alat peraga fisika inovatif. Rancangan disusun dengan melakukan tahap awal yaitu pengumpulan referensi mengenai materi fluida statis pada pokok bahasan hukum Archimedes yang bertujuan agar mendapatkan banyak sumber yang akurat untuk membuat alat peraga fisika inovatif.

Tahap selanjutnya adalah membuat desain tentang sensor air sederhana untuk jemuran otomatis dibuat sebagai alat peraga inovatif dan apa saja yang akan ditulis dalam buku pedoman penggunaan alat peraga fisika inovatif dan bagaimana urutan langkah penyajian materinya serta langkah-langkah penggunaan alat peraga tersebut. Produk ini diharapkan dapat meningkatkan produktivitas pembelajaran fisika di SMA Negeri 5 Yogyakarta.

\section{Development (tahap pengembangan)}

Setelah diperoleh rancangan alat peraga sains fisika, kemudian dilanjutkan dengan tahap pengembangan alat peraga meliputi tahap pembuatan atau penyusunan alat peraga sesuai dengan hasil perancangan yang diperoleh tersebut. Data kelayakan alat peraga sains fisika diperoleh dengan cara memberikan angket kepada ahli materi dan ahli media (dosen dan guru fisika). Angket tersebut berupa lembar penilain yang terdiri dari aspek isi buku, penyajian, kemanfaatan, dan pengoperasian dengan tujuan pembuatan alat peraga yang selanjutnya akan direvisi sesuai dengan masukan dari para ahli.

\section{Implementation (tahap implementasi)}

Dalam tahap ini, setelah produk melalui proses pengembangan dan revisi dari para ahli maka alat peraga fisika inovatif siap untuk diimplementasikan kepada siswa kelas X SMA Negeri 5 Yogyakarta.
Setelah menggunakan alat peraga fisika inovatif tersebut, siswa diminta untuk mengisi angket respon, kemudian siswa juga diminta untuk memberi tanggapan atau saran terhadap alat peraga tersebut.

5. Evaluation (tahap evaluasi)

Evaluasi adalah proses untuk melihat apakah media pembelajaran yang dikembangkan telah berhasil dan layak digunakan sebagai media pembelajaran atau tidak[5]. Pada tahap ini dilakukan proses untuk menganalisis hasil implementasi sebagai bahan perbaikan alat peraga. Masukan dari siswa kemudian dianalisis dan dilakukan revisi kembali pada bagianbagian alat peraga fisika inovatif yang belum sesuai. Setelah produk direvisi, maka produk akhir yang dihasilkan berupa alat peraga fisika inovatif pada materi fluida statis untuk siswa kelas X SMA Negeri 5 Yogyakarta telah teruji validasinya dan dapat dikatakan layak sebagai media pembelajaran.

Uji coba produk dilakukan terhadap para ahli, yaitu: ahli materi, ahli media dan pengguna yaitu siswa.

Data yang digunakan dalam penelitian pengembangan ini adalah:

I. Data Kualitatif

Data kualititatif berupa masukan, koreksi, dan kritik yang diberikan oleh dosen ahli materi, dosen ahli media, dan guru fisika terhadap alat peraga fisika inovatif.

2. Data Kuantitatif

Data kuantitatif adalah data hasil penilaian yang diperoleh dari lembar penilaian atau angket oleh ahli materi dan ahli media, angket respon siswa dan hasil belajar fisika siswa yang berupa pretest dan posttest.

Instrumen penelitian adalah alat yang digunakan peneliti untuk memperoleh data. Instrumen yang digunakan dalam penelitian ini adalah:

I. Lembar Penilaian Produk

Lembar Penilaian untuk dosen ahli materi, dosen ahli media dan guru fisika digunakan untuk menilai kualitas alat peraga sains fisika yang telah dikembangkan berdasarkan aspek isi buku, penyajian, kemanfaatan dan pengoperasian.

2. Angket Respon Siswa

Angket respon siswa digunakan untuk mengetahui bagaimana tanggapan siswa terhadap alat peraga dan kelayakan alat peraga. Dalam angket respon ini terdapat 3 aspek penilaian alat peraga sains fisika, yaitu kriteria pembelajaran, kriteria tampilan dan kriteria teknis.

3. Interview (wawancara)

Pedoman wawancara berisi daftar pertanyaan yang bertujuan untuk mengungkap informasi tentang metode pembelajaran yang biasa dilakukan oleh guru, kelayakan penyajian alat serta untuk mendapat saran 
Pengembangan Sensor Air Hujan Menggunakan Hukum Archimedes Untuk Jemuran Pakaian Otomatis Berbasis Lingkungan Sebagai Media Pembelajaran Fisika

dan masukan terkait alat peraga yang telah dikembangkan.

4. Tes hasil belajar fisika siswa (pretest dan posttest)

Tes hasil belajar fisika digunakan untuk mengukur pemahaman siswa terhadap kompetensi yang diajarkan. Uji kompetensi berupa soal pilihan ganda sebanyak 10 butir dan essay 2 butir dalam waktu I x 30 menit. Soal pilihan ganda memuat empat pilihan jawaban. Jika jawaban benar diberi skor I sedangkan jika jawaban salah diberi skor 0 . Untuk soal essay jika jawaban benar diberi skor 5 sedangkan jika jawaban salah diberi skor 0 .

a. Pretest

Pretest digunakan untuk mengetahui kemampuan awal siswa sebelum alat peraga di ujicobakan.

b. Posttest

Posttest digunakan untuk mengetahui kemampuan akhir siswa setelah alat peraga di ujicobakan.

5. Rencana pelaksanaan pembelajaran (RPP)

Rencana kegiatan peneliti yang berisi skenario pembelajaran tahap demi tahap mengenai aktivitas yang dilakukan siswa bersama peneliti.

Teknik analisis data sebagai berikut:

I. Data Kualitatif

Data kualitatif diperoleh dari hasil penilaian ahli materi, ahli media, dan pengguna yang berupa masukan, tanggapan, kritik, saran dan perbaikan yang berkaitan dengan alat peraga sains fisika yang dikembangkan. Tanggapan atau saran dari validator yang dianggap tepat untuk pengembangan alat peraga sains fisika maka akan digunakan sebagai bahan perbaikan pada tahap revisi alat peraga sains fisika.

2. Data Kuantitatif

Hasil penilaian oleh ahli materi, ahli media, dan angket respon siswa berupa data kuantitatif. Data tersebut kemudian dianalisis menggunakan pedoman pengkorvesian nilai. Nilai akumulasi ini merupakan jumlah nilai total dari setiap komponen penilaian. Data analisis menggunakan presentasi keberhasilan sebagai berikut [7].

$$
N P=\frac{R}{S M} \times 100 \%
$$

dimana:

$N P=$ nilai persen skor tiap aspek penilaian alat peraga sains fisika yang diharapkan (dicari)

$R=$ jumlah skor dari tiap aspek penilaian alat peraga sains fisika

$S M=$ skor maksimal tiap aspek penilaian alat peraga sains fisika
Dari persentase yang diperoleh kemudian ditransfer kedalam bentuk nilai, dan dikonversikan dalam bentuk tabel pedoman penilaian

\section{Hasil Penelitian dan Pembahasan}

\section{Analisis data dari ahli materi dan ahli media}

Setelah alat peraga sains fisika dinyatakan layak oleh dosen pembimbing, selanjutnya dilakukan proses penilaian oleh dua ahli materi dan ahli media. Hasil analisis penilaian instrumen oleh ahli materi dan ahli media terhadap alat peraga fisika dapat digambarkan seperti dalam diagram berikut.

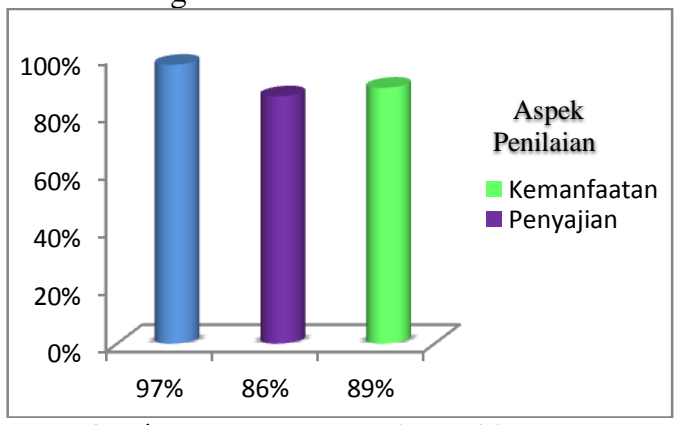

Gambar I. Diagram penilaian ahli materi

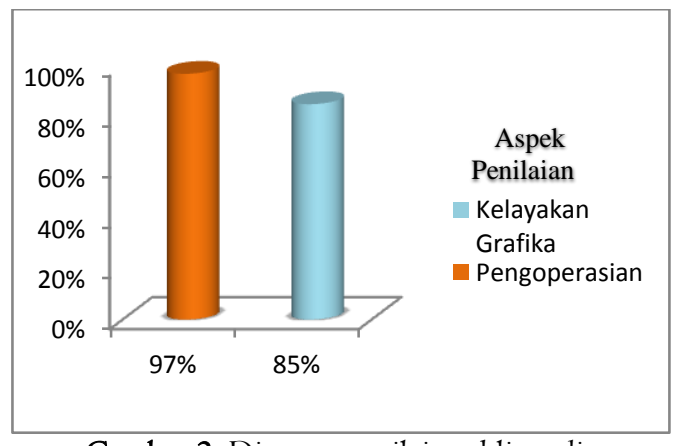

Gambar 2. Diagram penilaian ahli media

\section{Hasil Analisis Data Pretest dan Posttest}

Setelah alat peraga sains fisika dinyatakan layak oleh ahli materi, ahli media dan guru fisika, maka alat peraga fisika inovatif siap diimplementasikan kepada siswa SMA. Uji coba alat peraga fisika inovatif dilaksanakan di SMA Negeri 5 Yogyakarta kelas XMIA7 dengan melibatkan I5 siswa. Proses uji coba dilaksanakan pada tanggal I2 Januari 2015.

Dari data analisis terhadap hasil pretest, disimpulkan bahwa I5 siswa kelas XMIA7 sebelum menggunakan alat peraga fisika inovatif memperoleh nilai rata-rata 54,5. Hal ini menunjukkan bahwa pemahaman siswa pada saat pretest berada dalam kategori cukup baik. Dari data analisis terhadap hasil posttest, disimpulkan bahwa I5 
Pengembangan Sensor Air Hujan Menggunakan Hukum Archimedes Untuk Jemuran Pakaian Otomatis Berbasis Lingkungan Sebagai Media Pembelajaran Fisika

siswa kelas XMIA7 setelah menggunakan alat peraga memperoleh nilai rata-rata 84,33.

Dengan berpedoman pada konversi nilai, nilai rata-rata tersebut masuk dalam kategori baik dan terdapat perbedaan yang sangat signifikan pada hasil belajar siswa. Berdasarkan hasil analisis pretest dan posttest tersebut dapat disimpulkan bahwa pemahaman siswa dalam kegiatan pembelajaran menggunakan alat peraga lebih baik dan signifikan dalam meningkatkan hasil belajar.

\section{Hasil Analisis Angket Respon Siswa}

Setelah pelaksanaan uji coba selesai, siswa sebagai subjek uji coba diminta untuk mengisi angket respon siswa terhadap alat peraga fisika inovatif yang mereka gunakan dalam pem belajaran. Bila hasil angket respon siswa tersebut disajikan dalam bentuk diagram hasilnya dapat dilihat dibawah ini.

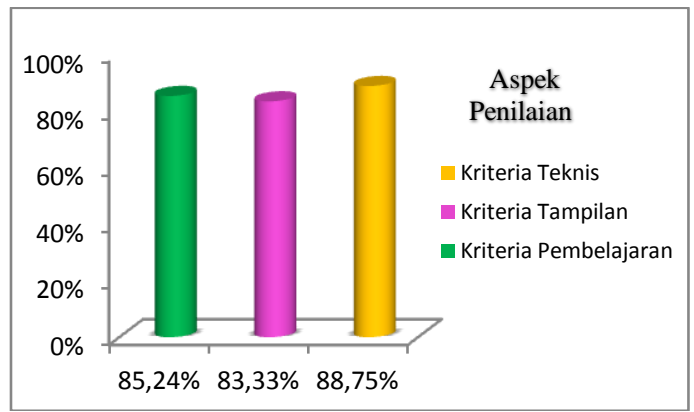

Gambar 3. Diagram analisis angket respon siswa

\section{Kesimpulan}

Berdasarkan hasil penelitian dan pembahasan diperoleh kesimpulan sebagai berikut:

I. Telah dikembangkan alat peraga fisika inovatif yang dapat dijadikan sebagai media pembelajaran fisika yang menarik dan bermakna pada materi fluida statis pokok bahasan hukum Archimedes untuk siswa SMA kelas X.

2. Alat peraga fisika inovatif dinyatakan layak digunakan sebagai media pembelajaran yang menarik dan bermakna pada materi fluida statis pokok bahasan hukum Archimedes untuk siswa SMA kelas X. Berdasarkan angket respon pada kriteria pembelajaran diperoleh $85,24 \%$, kriteria tampilan diperoleh $83,33 \%$, dan kriteria teknis diperoleh $88,75 \%$.

\section{Kepustakaan}

[I] Sanaky, Hujair. 2013. Media Pembelajaran Interaktif-Inovatif. Yogyakarta : Kaukaba Dipantara

[2] Hamalik, Oemar. 1989. Media Pendidikan. Bandung : PT. Citra Aditya Bakti

[3] Slamet, Agus. dkk. 2013. Pengaruh Penggunaan Alat Peraga Berbasis Lingkungan (APBL) pada Materi Dinamika Partikel terhadap Kemampuan Psikomotor. PI Peserta Didik Kelas X SMA Negeri I Kutowinangun. Jurnal Inkuiri. Vol. 4. No. I, 2013: 30-33

[5] Sugiyono. 2014. Metode Penelitian Pendidikan: Pendekatan Kuantitatif, Kualitatif, dan R\&D. Bandung: Alfabeta.

[6] Pribadi, Benny A. 2009. Model Desain Sistem Pembelajaran. Jakarta: Dian Rakyat.

[7] Purwanto, M. Ngalim. 2006. Prinsip-prinsip dan Teknik Evalusi Pengajaran. Bandung: PT Remaja Rosdakarya 